\title{
Translating Literary Prose: Problems and Solutions
}

\author{
Md. Ziaul Haque
}

Correspondence: Md. Ziaul Haque, Department of English, Sylhet International University, Shamimabad, Bagbari, Sylhet, Bangladesh. Tel: 880-19-3734-9506. E-mail: mdziaulhaque708@gmail.com

\author{
Received: August 27, 2012 Accepted: October 22, 2012 Online Published: November 29, 2012 \\ doi:10.5539/ijel.v2n6p97 \\ URL: http://dx.doi.org/10.5539/ijel.v2n6p97
}

\begin{abstract}
This article deals with the problems in translating literary prose and reveals some pertinent solutions and also concentrates on the need to expand the perimeters of Translation Studies. The translation courses offered at many universities in Bangladesh and overseas treat the subject mostly as an outcome of Applied Linguistics. Presently, the teachers and students of translation are confused at the mounting impenetrability of the books and articles that flood the market. Unfortunately, the translators lay more emphasis on the translation of poetry; there should be more research regarding the particular problems of translating literary prose. One explanation of this could be the fact that the status of poetry is considered higher, but it is more possibly due to the notable flawed notion that the novels, essays, fiction etc. possess a simple structure compared to that of a poem and is thus easier to translate. However, many debates have been organised over when to translate, when to apply the close local equivalent, when to invent a new word by translating clearly, and when to copy. Simultaneously, the "untranslatable" cultural-bound words and phrases have been continuously fascinating the prose-translators and translation theorists. The plea made in this article is to admit the fact that there is a lot to be learnt from shaping the criteria for undertaking a prose-translation and we should appreciate the hard work, difficulties, or frustration of the 'translators' (go-betweens) in the creation of good sense of the texts.
\end{abstract}

Keywords: translation, prose, problems, solutions, distant-author, prosaic-ideas, go-between

\section{Introduction}

Evidently, 'prose-translation' is the translation of novels, essays, fiction, short stories, comedy, folk tale, hagiography, works of criticism, science fiction etc. It is a type of literary creativeness where the written-work of one language is re-created in another. It is an inherent idea that the translation of poetry is very problematic, yet we have to agree that the translators also have to face lots of difficulties when it comes to translating prose. For example, the Wycliffe Bible (ca. 1382) was the original grand English translation and it illustrated the flaws of an English prose that was weak in nature. The great epoch of English prose translation started at the closing stages of the $15^{\text {th }}$ century with Thomas Malory's Le Morte d'Arthur, which was an adaptation of Arthurian romances and we can scarcely call it a proper translation. Accordingly, the earliest great Tudor renditions were the Tyndale New Testament (1525), which impacted the Authorized Version (1611), and Lord Berners' version of Jean Froissart's Chronicles (1523-25).

However, when the source and target languages belong to different cultural groups, the first problem faced by the prose-translator is finding terms in his or her own language that express the highest level of faithfulness possible to the meaning of certain words. For example, there are some words that are related to typical fabrics, cookery specialties, or jobs; they also represent specific culture and the translators should be very careful in translating such words. They also find it difficult to render ambiguous puns. Similarly, the titles of stories and novels provide many examples of such ambiguities, which are hard or even impossible to translate.

Many people think that the translation of literary works is one of the highest forms of rendition because it is more than simply the translation of text. A literary translator must also be skilled enough to translate feelings, cultural nuances, humour and other delicate elements of a piece of work. In fact, the translators do not translate meanings but the messages. That is why, the text must be considered in its totality. Alternatively, Peter Newmark (1988) delineates translation as "rendering the meaning of a text into another language in the way that the author intended the text" (p. 5). A further point is that there are examples in which the source text contains "facets' that are advocated in an apt manner by Lawrence Venuti (1995): “...discursive variations, experimenting with archaism, slang, literary allusion and convention" (p. 310). Additionally, it is no less than potentially 
contradictory that the translator should be "visible" and make use of "foreignising" attributes simultaneously, as foreignising attributes, at any rate in the Schleiermacher tradition, were chiefly initiated into the Target Text (T.T) from the Source Text (S.T), not by the translator's innovation.

Language has more than a communicative, or societal and connective purpose in literary-prose translation. The word works as the 'key ingredient' of literature, i.e. it has an arty function. A tricky course of action emerges between the start and the conclusion of an innovative work of translation, the 'trans-expression' of the life incarcerated in the framework of imagery of the work being translated. Hence, the problems in 'prose-translation' are within the area of art and they depend on its particular laws.

\section{The Essence of 'Translation' Guiding towards the 'Translation of Literary Prose'}

Plainly, the word "translation derives from the Latin translatio (which itself comes from trans- and fero, the supine form of which is latum, together meaning 'to carry across' or 'to bring across')" (Kasparek, 1983: 83). It "began only after the appearance of written literature" (Cohen, 1986: 12). It is the "communication of the meaning of a source-language text by means of an equivalent target-language text" (Bhatia, 1992: 1,051). In brief, to translate is to pour meaning from one vessel to another one that is equivalent to the first. Whereas, prose represents ordinary speech or writing, without metrical structure. It indicates "words in their best order" (Webster's Unabridged Dictionary, 1913). In other words, "Everything that is not verse is prose" ("Le Bourgeois Gentilhomme", 2010). So, concerning the mentioned definition, we can say that "thinking is translating 'prosaic-ideas' without accessories" since ideas (in brain) do not follow any metrical composition.

The subject, Translation Studies, was not given much importance earlier. Now, people's mentality seems to be changing; Octavio Paz (1971) abridges the case for Translation Studies saying that all texts are 'translations of translation of translations' as they are element of a literary system that not only slid down from other systems but also are connected with them. His view moderately echoes the notion of Terry Eagleton (1977) who supposes that "every text is a set of determinate transformations of other..." (p. 72). According to Paz,

Every text is unique and, at the same time, it is the translation of another text. No text is entirely original because language itself, in its essence, is already a translation: firstly, of the non-verbal world and secondly, since every sign and every phrase is the translation of another sign and another phrase. However, this argument can be turned around without losing any of its validity: all texts are original because every translation is distinctive. Every translation, up to a certain point, is an invention and as such it constitutes a unique text. (p. 9)

The translation of literary prose is different from literary creativity because its existence depends on the existence of an object of translation, a work to be translated. However, it is not always possible to sketch a separate border line in the real literary procedure between prose-translation and all creative literature. In some examples, a work may not be a translation in the common sense, but it may not be possible to express it absolutely as a work of literary creativeness. Several labels that are used to designate these works include- "open translation", "faux", "a work on the themes of", and "founded on". The particular meanings of these designations rely on the language and the eon.

Walter Benjamin (1996) presents the idea that a translation does not indicate an original text, it has no relationship with communication, its purpose is not to carry meaning, etc. The work of writing does not merely imitate or copy, but rather strives to extract and convey the essence of the previous text. But, it is not the message that is passed along in the good translation, Benjamin will say, for "what does a literary work 'say'? [...] it 'tells' very little" (p. 253). He shows the relationship between the supposed original and translation by using the symbol of a tangent: translation is like a straight line or curve, which touches the circle (i.e. the original) in one single point and follows its own way later: 


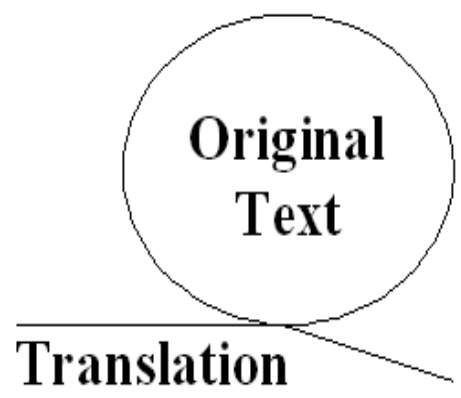

Figure 1. The Relationship between the Original Text and the Translated Version

At the very beginning, the translator keeps both the Source Language (S.L) and Target Language (T.L) in mind and tries to translate carefully. But, it becomes very difficult for a translator to decode the whole textbook literally; therefore, he takes the help of his own view and endeavours to translate accordingly. So, translation can be 'servitude' and 'freedom' (Vieira, 1999: 111). It is broadly accepted that 'the original text', 'the translated version', 'the language of the original' and 'the language of the translation' are constantly transformed in space and time. As the Brazilian translators consider

translator as cannibal, devouring the source text in a ritual that results in the creation of something completely new. (Cited in Bassnett, 1980: xiv)

Likewise, let us compare the role of a translator to that of a 'sati' particularly from the perspective of 'position'. "Spivak talks about the race and power dynamics involved in the prohibition of sati in "Can the Subaltern Speak?" (Sharp, 2008: Chapter 6). She often focuses on the cultural texts of the 'marginalized' by 'dominant western culture': the new immigrant; the working class; women; and other positions of the 'subaltern' (Spivak, 1990: 62-63); “... subaltern is not just a classy word for 'oppressed”" (De Kock, 1992: 29). We never hear from the sati-performing women themselves. Similarly, a question can be raised- 'Can the translator speak?' Sometimes, the translator can talk especially when the go-between (translator) becomes a get-between through the act of paraphrasing. If a translator's “'thinking' is writing without accessories" (Cited in Dimitriu, 2002: 227), then it will not be irrational to state that he speaks constantly through his pen, pencil and keyboard!

Nonetheless, numerous publishers, reviewers and readers accept a translated text if it is fluently readable, if it reflects the foreign author's individuality or purpose or the fundamental sense of the foreign book - that the translation is not a translation in reality, but the original. Incidentally, the prose-translators can learn many things from Jhumpa Lahiri. She, her parents being Bengali, was born in London, grew up in America and became an American inhabitant at age 18 . She admits that she is not really a bilingual and has written fiction not only about Indians in America but also some stories about Indians who are still living in India. Many people criticise her by saying that she, in her stories, has portrayed India in unclear, untrue and faulty manner. But, it is really painful for any writer living far away in a new state, leaving his/her own homeland behind; the motherland, the environment, people, culture etc. constantly echo in the writer's (and of course anybody else's) mind. So, the manner of trying to imagine and describe about the motherland and its people deserves esteem. I think that we should coin a new term, i.e. "distant-author" and add it to Lahiri's name since she, being a part of another country, has taken the help of 'imagination' and depicted her India the way she has wanted to; the writer must have every possible right to paint the world the way he/she thinks appropriate. However, Lahiri (2000) sounds extremely polite in saying that

I am the first person to admit that my knowledge of India is limited, the way in which all translations are. (p. 118)

Let us ponder over the translation-equivalence-concept now. The idea swings between literal and free, faithful and beautiful, exact and natural translation, depending on whether the bias was to be in favour of the author or the reader, the source or target language of the text (Newmark, 1988). However, the "dynamic equivalent translation" is very important and the translators (particularly prose-translators) should have a lucid idea about this 
phenomenon. The translation theorists view dynamic equivalence as a translation code; according to this very code, a translator looks for rendering the meaning of the original in such a way that the T.L readers will definitely enjoy the text as is done usually by the source text readers. Both Eugene A. Nida and C. Taber (1982) argue that

Frequently, the form of the original text is changed; but as long as the change follows the rules of back transformation in the source language, of contextual consistency in the transfer, and of transformation in the receptor language, the message is preserved and the translation is faithful. (p. 200)

It is evidently mentioned by them that the dynamic equivalence in translation is far more than mere correct communication of information. Nida says that the definition of a dynamic equivalent translation is to describe it as "the closest natural equivalent to the source-language message". This definition includes three essential terms, namely

1. Equivalent, which refers to the source-language message,

2. Natural, which refers to the receptor language, and

3. Closest, which "binds the two orientations together on the basis of the highest degree of speculation".

Natural indicates three areas of the communication process: a natural description should fit the total receptor language and culture, the context of the specific message, and the receptor-language audience. Therefore, the translation should bear no clear trace of a foreign origin. The following diagram shows that the translator is both recipient and emitter:

\section{Writer - Book - Recipient $-=$ Translator - Book - Recipient}

Figure 2. The Distinct Role of the Translator

However, Homi K. Bhabha's belief about translation is quite different and complicated as compared to the view of Nida. For instance, Bhabha (1994) begins with an epigraph from Walter Benjamin's classic essay on translation, "Translation passes through continua of transformation, not abstract ideas of identity and similarity" (p. 212). Jacques Derrida (1985) mentions "in this context, Benjamin still says "communication" or "enunciation" (Mitteilung, Aussage), it is not about the act but about the content that he visibly speaks: "But what does a literary work [Dichtung] 'say'? What does it communicate?" (p. 181). "Gasche suggests... that language communicates communicability itself" (Rendall, 1997: 168). According to Bhabha (1994), "translation is the performative nature of cultural communication" (p. 228). Now, Jacques Derrida (2004) suggests that "the question 'what is translation' implies, as if synonymously, "what should the best possible translation be" (p. 430). Here, a 'simile' deriving from Seneca (and Horace), deserves to be mentioned since it "compares the relationship between a 'new' text and its antecedent to the relationship between honey and the flowers from which it is produced" (Petrarch, 1985: 301-302).

In other words, we translate texts, sentences etc. and this process helps us to communicate with other people having different cultural roots. "The sign of translation frequently tells, or 'tolls' the different times and spaces between cultural authority and its performative practices" (Lloyd, 1987: 110-111). The 'time' of translation consists in that movement of meaning, the principle and practice of a communication that, in the words of P. de Man (1986) 'puts the original in motion to decanonise it giving it the movement of fragmentation, a wandering of errance, a kind of permanent exile' (p. 92). There is nothing problematic in this view. But, we cannot entirely support Gasche's (1988) view that translation is "language in actu (enunciation, positionality) rather than language in situ (enonce, or propositionality)" (p. 92). The 'enonce' indicates 'what is said' and the 'enunciation' refers to 'the act or process of saying it'. Conceivably, in my opinion, translation is language in actu as well as in situ because it (translation) includes not only the 'process' of saying something but also the 'said' or 'presented' text or texts.

In his article, "On Linguistic Aspects of Translation", Roman Jakobson directly indicates the innermost difficulty in every category. He is of the view that there is normally no full equivalence through translation while messages may possibly serve as satisfactory analyses of code units or messages. The French theorist, Georges Mounin agrees with Jakobson. The former

perceives translation as a series of operations of which the starting point and the end product are 'significations' and function within a given culture. (Cited in Susan Bassnett, 1980: 15) 


\section{Problems in Translating Literary Prose}

Translation is a challenging activity and there are few difficulties that emerge throughout the translation process since every language portrays the world in diverse way and has its own grammar structure, grammar rules and syntax variance. For example, Greek has separate words for 'light blue' and 'dark blue', while other languages, such as Welsh and Japanese, have words that can denote 'blue' or 'green', or something in between. In the title of Nicole Brossard's book (L'Amèr, ou le chapitre effrité), "l'amèr" is a multifaceted pun, which contains at least three French words: "mère" (mother), "mer" (sea), and "amer" (bitter)" (Cited in Dimitriu, 2002: 171). As Zhongde (1991) says:

The difficulty in translation just lies in the fact that both the content and the style are already existent in the original and as a result, you will have to do your best to reproduce them as they are in quite a different language. (p. 7)

The most particular problems that the translators face include- illegible text, missing references, several constructions of grammar, dialect terms and neologisms, irrationally vague terminology, inexplicable acronyms and abbreviations, untranslatability, intentional misnaming, particular cultural references etc. Nonetheless, there are some theorists who think that 'literal translation' is not possible. They present three main reasons supporting their stance:

1. Because a particular word in one language often contains meanings that involve several words in another language. For example, the English word 'wall' might be rendered into German as Wand (inside wall) or as Mauer (exterior wall),

2. Because grammatical particles (verb tenses, singular/dual/plural, case markers etc.) are not available in every language, and

3. Because idioms of one language and culture may be utterly perplexing to speakers from another language and culture.

"Language is in the nature of man" (Benveniste, 1971: 223-224) and "provides the very definition of man" (Adams and Searle, 1986: 729). Edward Sapir claims that human beings are at the mercy of the language that has become the medium of expression for their society and culture; language habits of the group of people determine experience generally and every disjointed structure signifies a separate authenticity. The translators encounter the complexities of differences between cultures; the subject of 'cultural difference' is very problematic and Walter Benjamin (1968) has described it as "the irresolution, or liminality, of 'translation', the element of resistance in the process of transformation, 'that element in a translation which does not lend itself to translation"' (p. 75). Sapir (1956) utters:

No two languages are ever sufficiently similar to be considered as representing the same social reality. The worlds in which different societies live are distinct worlds, not merely the same world with different labels attached. (p. 69)

Conversely, 'equivalence' consists of many countenances; for instance, it is an essential condition for translation, an obstruction to advancement in Translation Studies, or helpful category for analysing translations. Sometimes, it is 'damaging' (Gentzler, 1993) or 'irrelevant' (Snell-Hornby, 1988: Chapter 5). The domain of equivalence covers linguistic units such as morphemes, words, phrases, clauses, idioms and proverbs. "Most translators are used to it (equivalence) rather than because it has any theoretical status" (Baker, 1992: 5-6). Catford (1965) opines that

the central problem of translation practice is that of finding T.L (target language) equivalents. A central task of translation theory is therefore that of defining the nature and conditions of translation equivalence. (p. 21)

The translators, through using equivalence approaches, also endeavour to influence their readers by the 'standard translation'. Yet, the notion of equivalence creates several problems since we can interpret it in miscellaneous manners. Both the words as well as context are considered in equivalence. In this connection, Catford (1965) simply puts forward that translation is the "substitution or replacement of textual materials in one language by equivalent textual material in another language" (p. 20). But, his linguistic theory of translation was not (and is not) accepted liberally by many. Snell-Hornby (1988) argues that Catford's definition of textual equivalence is 'circular', his hypothesis' dependence on bilingual informants 'hopelessly inadequate', and his model sentences 'isolated and even absurdly simplistic' (pp. 19-20). She reckons that the perception of equivalence in translation is nothing but a 'delusion'.

Let us extend the question of 'semiotic transformation' by considering the translation of a simple noun, butter. 
Weedon (1987) explains that Saussure's theory of the sign includes the following ideas, "each sign is made up of a 'signifier' (significant sound or written image) and a 'signified' (signifie meaning)" (p. 23). The structural relationship between the signified (signifie) or concept of butter and the signifier (significant) or the sound image made by the word butter shapes the linguistic sign butter. Susan Bassnett (1980) claims that "when translating butter into Italian, there is a straightforward word-for-word substitution: butter-burro" (p. 19). However, we cannot say that both butter and burro are the same because these possess different cultural frameworks. Normally, burro has a light colour and it is not salted; people use it in Italy mainly for cooking purpose; obviously, it has nothing to do with high status. Alternatively, butter is most often bright, yellow and salted in Britain and people use it by spreading on bread and in food preparation.

Some theorists may think that the common idiom bread and butter is faulty because the product used may even be 'margarine'. However, we cannot totally agree with this matter since the cited idiom is genuine and, thus, is an essential part of the native speakers' English. Nevertheless, it would be rather logical to say that this particular idiom is 'ambiguous'. Actually, the mentioned idiom is widely accepted since butter holds a lofty position. "So, there is a distinction both between the objects signified by butter and burro and between the function and value of those objects in their cultural context. The problem of equivalence here involves the utilization and perception of the object in a given context. The butter-burro translation, whilst perfectly adequate on one level, also serves as a reminder of the validity of Sapir's statement that each language represents a separate reality. The word butter describes a specifically identifiable product, but in the case of the word with a wider range of S.L meanings, the problems increase" (p. 19). There are some signifiers, such as truth, that we seem unable to do without. However, if we are to think differently, we must question the received meaning of such signifiers. Thus, we may choose to write sous rature, which Gayatri Spivak (1974) translates 'as 'under erasure'. This is to write a word, cross it out, and then print both word and deletion. (Since the word is inaccurate, it is crossed out. Since it is necessary, it remains legible.)" (p. xiv). However, Boris Uspensky (1973) states that

symbolic description 'must be double'; for, 'the wise artist probably spends his greatest effort to keep his images, which have become symbols, from slipping from their pedestals of esthetic isolation and mixing with life, like elements which are homogeneous with it'. (p. 139)

Nida's (1964) diagrammatic drawing of the semantic structure of spirit (p. 107) shows a more intricate set of semantic relationships; it indicates that we can use a word in witticism and banter. Then, the translator must be careful about the particular use of spirit in the sentence itself, in the sentence in its structural relation to other sentences, and in the general textual and cultural situations of the sentence. Otherwise, there will be mistranslation and the readers will become confused. So, for example, The spirit of the dead child rose from the grave points to 7 and not to any other of Nida's categories, while The spirit of the house lived on might designate 5 or 7 or, if we think from the standpoint of symbol, 6 or 8 . Obviously, the correct translation depends on the 'context'.

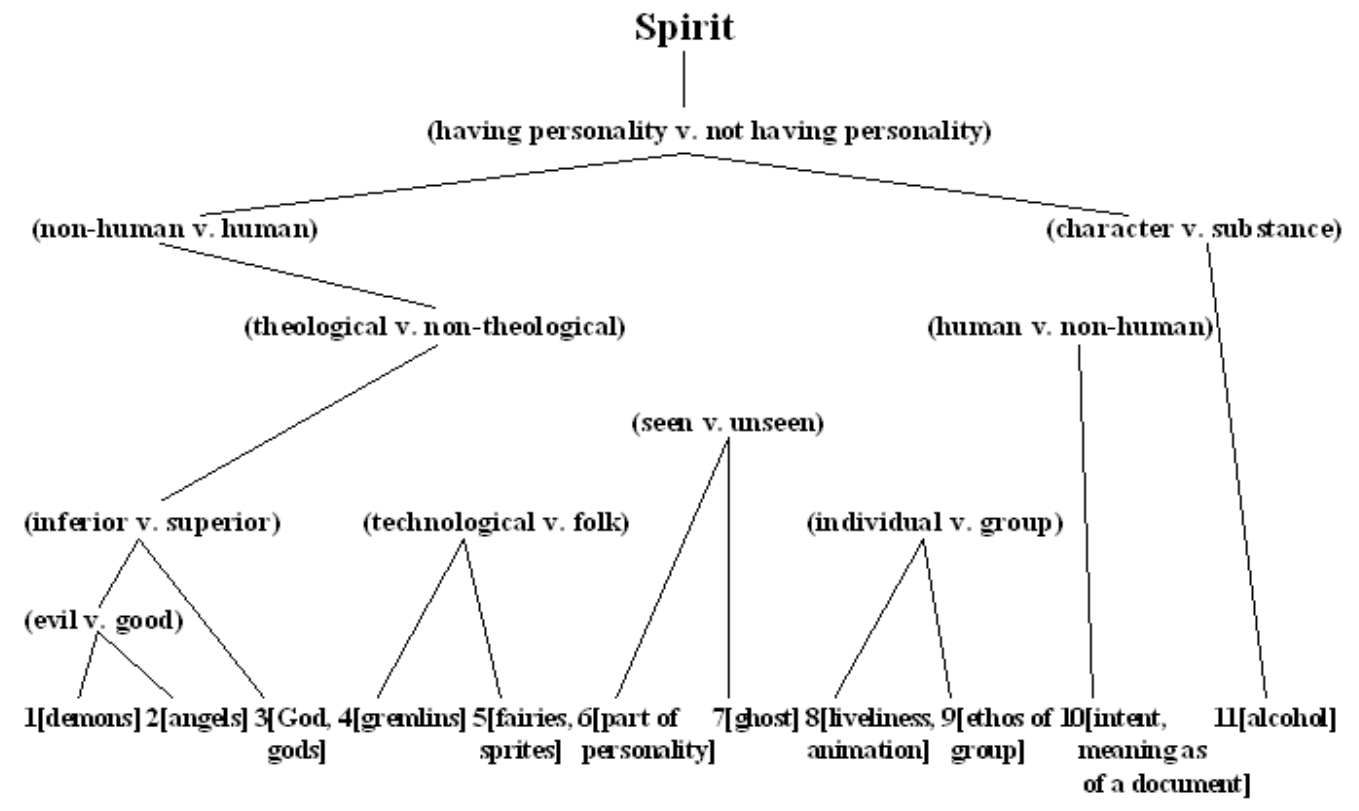

Figure 3. The Semantic Structure of 'Spirit' 
Unfortunately, many prose-translators fail to understand that a literary text is a combination of a complex set of systems that exist in a dialectical relationship with other sets outside its boundaries; this kind of failure has regularly led them to concentrate on particular parts of a text at the cost of others. It seems to be easier for the (careless) prose-translator to consider content as separable from form. In this connection, a suitable example shows what may happen when a translator emphasises content at the expense of the entire structure. The first chapter, titled "Arrival”, of Thomas Mann's (1984) The Magic Mountain begins in the following manner:

An unassuming young man was travelling in midsummer, from his native city of Hamburg to Davos-Platz in the Canton of Grisons, on a three weeks' visit.

From Hamburg to Davos is a long journey - too long, indeed, for so brief a stay. It crosses all sorts of country; goes up hill and down dale, descends from the plateaus of Southern Germany to the shores of Lake Constance, over its bounding waves and on across marshes once thought to be bottomless. (p. 1)

Of course, this is a very dynamic, lively passage. It consists of three sentences with four verbs of action and movement; the reader is dragged straight into the narrative by the passage. Briefly, the opening is strong and descriptive and has an influential authorial existence; besides, the depiction of the world has got the touch of realism in it. But, the problem with this translation emerges especially when we compare it to the original German text. Mann's (2011) novel starts in the following way:

Ein einfacher junger Mensch reiste im Hochsommer von Hamburg, seiner Vaterstadt, nach Davos-Platz im Graubundischen. Er fuhr auf Besuch fur drei Wochen.

Von Hamburg bis dorthinauf, das ist aber eine weite Reise; zu weit eigentlich im Verhaltnis zu einem so kurzen Aufenthalt. Es geht durch mehrerer Herren Lander, bergauf and bergab, von der suddeutsshen Hochebene hinunter zum Gestade des Schwabischen Meeres und zu Schiff uber seine springende Wellen hin, dahin uber Schlunde, die fruher fur unergrundlich galten. (p. 1)

In this opening passage, we can find a number of hints; the novel is set in a sanatorium where the characters are 'on holiday'. They are not worried about the struggle for survival. Hence, the voyage portrayed in the first few sentences is working as- the young man's real voyage; the figurative voyage across a country; a symbol for the journey that we (the readers) are about to start.

Moreover, there are decisive devices. For example, Mann uses the traditional expression 'Gestade' for 'shore' in describing the journey and this fact reminds us of the eighteenth-century styles. It seems to us that he has done so with a view to bringing the lyrical and the prosaic stylistic modes together. The English translator (H.T. Lowe-Porter) has made Mann's sentence-structures compact. Thus, she has reduced the number of levels on which the reader can approach the text. Perhaps, she has done so only to create a sense of fast movement. So, the second sentence has been integrated with the first one to shape a solitary unit and the fourth sentence has been reduced by intentional omissions, e.g. 'zu Schiff' (by boat). The translator has translated the word, 'einfacher' (ordinary) as 'unassuming' and this action of the English translator has surely introduced an influential part of characterization and changed the readers' outlook. Moreover, the translator has not laid much emphasis on the novel and this fact is proved with the visible mistranslation of the word, 'Schlunde', (meaning 'abysses') translated as 'marshes'. Incidentally, Wolfgang Iser (1974) indicates that

the intentional correlatives disclose subtle connections which individually are less concrete than the statements, claims and observations, even though these only take on their real meaningfulness through the interaction of their correlatives. (p. 277)

Actually, the sentence does not consist only of a statement but aims at something beyond what it actually says. Within a literary text, sentences always indicate something that is to come and their particular content foreshadows the structure. There may be a loss of element if the translator handles sentences for their definite content only. I think that the English translation of the above stated text has lost its acceptability because the translator has overlooked the section units in a complex general structure. The English editions show some types of negative shift relating

1. mistranslation of information,

2. subinterpretation of the original text,

3. superficial interpretation of connections between intentional correlatives.

Some readers may not support the act of putting so much importance on the cases of negative shift that come out from the opening few sentences of The Magic Mountain. We must agree with the fact that the analysis of the narrative has had vast influence ever since Shlovsky's early hypothesis of prose. Each key text is a combination of a series of interconnected schemes and has a determinable role concerning the whole piece. The translator of 
Mann has not considered the function of the description of both the young man and the journey; consequently, she has failed to understand the reasons for Mann's selection of language; evidently, mistranslation has taken place.

Let us consider another significant example; the prose-translators find it very difficult to translate proper names. “"Babel': first a proper name, granted. But when we say "Babel” today, do we know what we are naming? Do we know whom? If we consider the sur-vival of a text that is a legacy, the narrative or the myth of the tower of Babel, it does not constitute just one figure among others... It would not be the only structure hollowing itself out like that, but it would do so in its own way (itself almost untranslatable, like a proper name), and its idiom would have to be saved" (Derrida, 1985: 165). Voltaire showed his astonishment at the Babel article in his Dictionnaire philosophique, "I do not know why it is said in Genesis that Babel signifies confusion, for $B a$ signifies father in the oriental tongues, and Bel signifies God..." (Cited in Derrida, 1985: 166). Voltaire's irony suggests that "Babel means: it is not only a proper name, the reference to a pure signifier to a single being - and for this reason untranslatable" (Derrida, 1985: 166).

Likewise, Russian proper names generate misunderstanding in Russian texts. In this connection, a paragraph from Cathy Porter's translated version of Alexandra Kollontai's (1977) Love of Worker Bees is worth mentioning:

Russians have a first ('Christian') name, a patronymic and a surname. The customary mode of address is first name plus patronymic, thus, Vasilisa Dementevna, Maria Semenovna. There are more intimate abbreviations of first names which have subtly affectionate, patronizing or friendly overtones. So for instance Vasilisa becomes Vasya, Vasyuk, and Vladimir becomes Volodya, Volodka, Volodechka, Volya. (p. 226)

Here, we can clearly observe that the translator explains the naming system of Russia. The "transvaluation of the symbolic structure of the cultural sign is absolutely necessary so that in the renaming of modernity there may ensue that process of the active agency of translation - the moment of 'making a name for oneself' that emerges through "the undecidability ... [at work] in a struggle for the proper name within a scene of genealogical indebtedness"' (Derrida, 1985: 174). But, Cathy Porter has maintained the variations of name in the T.L version and this matter will surely create problems for an English reader because the latter is not exactly accustomed to the fact that the same character may have plethora of names on a single page. Briefly, we can say that a kind of transportation of S.L system into the T.L system is at work here. But, this process leads the readers towards confusion and they will gradually lose interest in reading the text more. By the way, Susan Bassnett (1980) mentions:

It is of little use for the English reader to be given multiple variants of a name if he is not made aware of the function of those variants, and since the English naming system is completely different, the translator must take this into account and follow Belloc's dictum to render 'idiom by idiom'. (p. 119)

It is only one instance whereby the translators face problems to translate S.L system into a T.L, which is devoid of any equivalent system. Boris Uspensky (1973) believes that the use of names in Russian can denote shifts in 'point of view' (Cited in Bassnett, 1980: 119). In contrast, Robert M. Adams (1973) lays more emphasis on the regional linguistic devices that are associated with a particular area or category in the S.L:

Paris cannot be London or New York, it must be Paris; our hero must be Pierre, not Peter; he must drink an aperitif, not a cocktail; smoke Gauloises, not Kents; and walk down the rue du Bac, not Black Street. On the other hand, when he is introduced to a lady, he'll sound silly if he says, 'I am enchanted, Madame'. (p. 12)

In this regard, let us talk about another vital example. "The fundamentalist charge has not focused on the misinterpretation of the Koran, as much as on the offence of the 'misnaming' of Islam... It is the formal complaints of the fundamentalists that the transposition of these sacred names into profane names... is not simply sacrilegious, but destructive of the very cement of community" (Bhabha, 1994: 273) what Alisdair Macintrye (1988), has described as 'naming for: the institutions of naming as the expression and embodiment of the shared standpoint of the community, its tradition of belief and enquiry' (p. 378). "British/India, Nostromo, ouboum - each cultural naming represents the impossibility of cross-cultural identity or symbolic synapses; each time there repeats the incompletion of translation" (Bhabha, 1994: 130).

However, the prose-translator has the right to differ organically, to be independent, if that independence is followed for the benefit of the original in order to reproduce it as a living work. Let us shed light on a very different, interesting and important aspect of translation itself to realise the depth and exact value of translation. 
Chinua Achebe's (1958) early work of fiction should express this point:

Mr. Smith said to his interpreter: Tell them to go away from here. This is the house of

God and I will not live to see it desecrated.

Okeke interpreted wisely to the spirits of Umuofia: The white man says he is happy you have come to him with your grievances like friends. He will be happy if you leave

the matter in his hands. (p. 134)

Surely, this is a planned mistranslation. At this point, the translator figure has told a lie; though he has lied to avoid a quarrel, he is not only cheating himself but also has turned into a traitor or cheat in the readers' eyes. Now, this example is enough to emphasise the need to change the idea of translation; the translator should not distort the meanings of the content that he is translating; he should be honest. Hillaire Belloc (1931) sums up the problem of status:

... it (translation) has never been granted the dignity of original work and has suffered too much in the general judgment of letters. This natural underestimation of its value has had the bad practical effect of lowering the standard demanded, and in some periods has almost destroyed the art altogether. (Cited in Susan Bassnett, 1980: 2)

\section{Solutions for the Translators of Literary Prose}

Initially, the translation of literary works - novels, short stories, plays, poems, etc. - is considered a literary recreation in its own right. However, as far as the solutions are concerned, the prose-translators should start with the careful adherence to the following principles:

1. a great understanding of the language, written and verbal, from which he is translating i.e. the source language;

2. an excellent control of the language into which he is translating i.e. the target language;

3. awareness of the subject matter of the book being translated;

4. a deep knowledge of the etymological and idiomatic correlates between the two languages; and

5. a delicate common sense of when to metaphrase or 'translate literally' and when to paraphrase, in order to guarantee exact rather than fake equivalents between the source- and target-language texts.

Moreover, the prose-translators can unite some of the following methods to deal with the translation problems efficiently.

1. Back Translation: "Comparison of a back-translation with the original text is sometimes used as a check on the accuracy of the original translation..." (Crystal, 2004: 5). It is one of the most familiar practices used to search for equivalents through:

a. The translation of items from the source language to the target language.

b. Free translation of these back into the source language.

2. Conference with Other People: Discussions about the use and meaning of words with bilingual people around a table to make decisions about the best terms to use.

3. Interviews or Questionnaires or Any Kind of Tests: These are used to remove translation-related difficulties.

Besides, the translators should keep the translation shifts in mind. J.C. Catford (1965) describes them as "departures from formal correspondence in the process of going from the S.L to the T.L" (p. 73). He believes that there are two major kinds of translation shifts, i.e. level shifts, where the S.L item at one linguistic level, e.g. grammar, has a T.L equivalent at a different level, e.g. lexis, and category shifts that have been categorised into four kinds:

1. Structure-shifts involving a grammatical alteration between the structure of the Source Text and that of the Target Text;

2. Class-shifts, when a Source Language item is translated with a Target Language item belonging to a diverse grammatical group, i.e. a verb may be translated with a noun;

3. Unit-shifts involving alterations in position; 
4. Intra-system shifts, which occur when "S.L and T.L possess systems which approximately correspond formally as to their constitution, but when translation involves selection of a non- corresponding term in the T.L system" (Catford, 1965: 80). For example, when the S.L singular becomes a T.L plural.

According to Nico Wiersema (2004), cultures are getting closer and closer and this is something that the translators need to take into account. Now, the problems in translating literary prose can be solved much if the prose-translator is both bilingual and bicultural. Thierry (1978) states that 'perfect bilingual' (p. 145) implies two things:

1. One speaks both the languages consistently well.

2. One has two mother tongues.

Wiersema's view is very much similar to the philosophy of Nida who believes that translation tries to connect a wide cultural gap and it is not possible for the prose-translators to remove all the marks of the foreign setting. According to him, it is normal that the source and receptor languages may possibly represent very different cultures that may include many basic themes and descriptions, which we cannot 'naturalise' by the process of translating. By entering the S.L cultural elements:

1. the text will be more 'fluently-readable' (no stops),

2. the text continues to be more foreign, more distant,

3. the translator comes nearer to the source culture, and

4. a more authentic picture of the source culture appears before the reader of the target texts. (Wiersema, 2004: Volume 8, No. 1)

Correspondingly, a natural translation must also be in reference to the situation of the specific message, which could include not only the grammatical and lexical elements but also detailed matters such as intonation and sentence rhythm. However, Harris and Sherwood (1978) are of the view that a natural translator has to go through the following stages:

1. 'Pre-translation', where the translator typically uses single words,

2. 'Auto-translation', whereby the translator translates to others what he has said or written himself,

3. 'Transduction' whereby the translator works as a mediator between two other people. (pp.165-166)

As indicated by Nida, naturalness of expression in the receptor language is mainly a problem of co-suitability. According to his model, the usual process of translation looks like the following:

\section{SOURCE LANGUAGE}

\section{RECEPTOR LANGUAGE}

TEXT<smiles>C=CC(C)C</smiles>

ANALYSIS
TRANSLATION

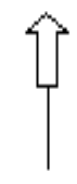

RESTRUCTURNG

\section{TRANSFER}

Figure 4. The Process of Translation 
Therefore, the principles, managed by the translator, go further than the exclusively linguistic, and decoding as well as recoding processes take place. Ultimately, it all depends on what the translator, or more often, the publisher wants to achieve with a certain translation.

In translation, the study of equivalence demonstrates the way the translators correctly render the text in translation from S.L into T.L or vice versa. "Equivalence, for example, while discredited in the 1980s yet tends to be reintroduced by scholars..." (Snell-Hornby, 1988: Chapter 5). As the goal of translation is to establish a relationship of equivalence between the source and the target texts, a successful translation can be judged by two criteria:

1. Faithfulness or Fidelity (accurate translation of the meaning of the source text, without adding to it or subtracting from it), and

2. Transparency (maintaining the grammatical, syntactic and idiomatic conventions of the target language).

A translation meeting the first criterion is called "faithful translation"; a translation meeting the second principle is known as "idiomatic translation". According to Halverson (1997), "Equivalence is defined as a relationship existing between two entities and the relationship is described as one of likeness/ sameness/ similarity/ equality in terms of any of a number of potential qualities" (p. 207). As said by Dorothy Kenny (1998), "Unfortunately, a few attempts have been made to define equivalence in translation in a way that avoids this circularity" (pp. 77-80). "Since the ideal could not be realized, there arose a practical necessity for compromises, which paved the way to countless debates over exactly how 'faithful' faithfulness should be and just how 'equivalent' is the equivalent" (Bassnett and Lefevere, 1998: 2). Yet, Pym Anthony (1992) states that

...equivalence is supposed to define translation, and translation, in turn, defines equivalence. (p. 37)

Moreover, Mona Baker's In other words: A Coursebook on Translation is a very informative book that is full of scholarly discussions on 'equivalence'. She investigates the idea of equivalence at diverse stages concerning the process of translation, together with all the varied features of translation. She categorises equivalence in the following manners:

1. Word Level and above Word Level Equivalence means that the translator should pay attention to a number of factors when considering a single word, such as number, gender and tense (Anthony, 1992: 11-12).

2. Grammatical Equivalence, when indicating the variety of grammatical classes (number, tense and aspects, voice, person and gender) across languages.

3. Textual Equivalence, when indicating the equivalence between S.L text and T.L text concerning information and consistency. Three main factors will guide the translator's decision, i.e. 'the text type', 'the purpose of the translation', and 'the target audience'.

4. Pragmatic Equivalence, when indicating implicatures and policies of evasion all through the translation procedure. "Implicature signifies what is suggested in an utterance." (Blackburn, 1996: 188-89). The role of the translator is to re-establish the author's purpose in another culture in such a way that facilitates the 'target culture (T.C) readers' to comprehend it clearly.

Vinay and Darbelnet (1995) view equivalence-oriented translation as a process that "replicates the same situation as in the original, whilst using completely different wording" (p. 342). According to them, equivalence is the perfect technique when the translator is dealing with idioms, proverbs, clichés, nominal or adjectival phrases and the onomatopoeia of animal sounds. Again, Vinay and Darbelnet assert that the equivalent expressions between language pairs can be granted only if we get them as a list in a bilingual thesaurus as 'full equivalents' (p. 255). They conclude by declaring that

the need for creating equivalences arises from the situation, and it is in the situation of the S.L text that translators have to look for a solution. (p. 255)

Certainly, they argue that it is not enough to quote (in a dictionary or a glossary) the semantic equivalent of an expression in the S.L text, and it does not ensure that the translation will be a successful one. They give numerous instances supporting their theory, and the following expression appears in their list: "Take one is a fixed expression which would have as an equivalent French translation Prenez-en un. However, if the expression appeared as a notice next to a basket of free samples in a large store, the translator would have to look for an equivalent term in a similar situation and use the expression Échantillon gratuity" (p. 256).

Roman Jakobson (1959) states that there is a very important alternative for the translators, who can complete the task from the standpoint of creative transposition. Jakobson's study of equivalence gave new momentum to the speculative study of translation since he initiated the notion of 'equivalence in difference'. He believes that 'there 
is no signatum without signum' (p. 232) and recommends three types of translation on account of his semiotic approach to language:

1. Intralingual Transposition: (within one language, i.e. restatement or paraphrase) from one lyrical shape into another,

2. Interlingual Transposition: (between two languages) from one language into another, and

3. Intersemiotic Transposition: (between sign systems) one system of signs into another, e.g. from verbal art into music, dance, cinema or painting.

In the case of interlingual translation, Jakobson maintains that the translator uses synonyms to get the meaning of the S.T. This indicates that the complete equivalence is absent between code units in interlingual translations. According to his theory, "translation involves two equivalent messages in two different codes" (p. 233). He acknowledges that "whenever there is deficiency, terminology may be qualified and amplified by loanwords or loan-translations, neologisms or semantic shifts, and finally, by circumlocutions" (p. 234). Notably, Vinay and Darbelnet's 'hypothesis' of translation processes matches Jakobson's one. The "translators have all the rights as long as their game is played upfront" (Berman, 1995: 76). Additionally, the prose-translators should follow the six principles presented by Hillaire Belloc (1931):

1. The translator must regard the work as an integral unit and translate in sections.

2. The translator must decode 'idiom by idiom'.

3. The translator ought to translate 'intention by intention' hinting the heaviness a particular term might contain in a meticulous situation in the S.L that would be asymmetrical if translated exactly into the T.L.

4. Belloc warns against les faux amis, those words or formations that may possibly come out to match up in both S.L and T.L but actually do not. For example, 'demander- to ask', translated incorrectly as to 'demand'.

5. The translator is supposed to 'alter courageously'.

6. The translator must never overstate.

Through these six principles, Belloc suggests the translator to view the prose text as a structured 'whole'; if the translator thinks in this manner, then it will be easier for him to translate and the translated text will be a good one. Besides, the translator must not forget the stylistic and syntactical requirements of the T.L. Many theorists believe that the translator has the right to change the text much in the translation procedure. In fact, the translator has the liberty to do it intentionally because, while translating, he has to keep the T.L stylistic and idiomatic norms in mind. If he does so, then the T.L readers will be able to enjoy the text more. Likewise, Susan Bassnett believes that the shift of emphasis from the original to translation is reflected in discussions on the 'visibility' of the translator. Whereas, Lawrence Venuti supports a 'translator-centred' translation.

Belloc's first point suggests the translator to block out his work. However, there is a problem related to this factit will be difficult to form translation units. We must not forget that the text is the main part. Nevertheless, the poet translator's task is much easier; he can break the main text down into translatable parts, e.g. lines, verses, stanzas. Alternatively, the prose-translator's task is more difficult. Surely, we can break down many novels into chapters or sections, but the structuring of a prose text is not, by any means, as linear as the chapter divisions might signify. However, there is a risk of the occurrence of mistranslation if the translator takes each sentence or paragraph as a minimum unit and translates it without connecting it with the general work.

The prose-translators must not think that any bilingual individual is able to produce satisfactory or even high-quality document translations simply because he is a fluent speaker of a second language. The ability, skill and even the basic mental processes required for bilingualism are mostly different from those required for translation. Primarily, the prose-translators must be able to read, understand and cling to somebody else's thoughts, then translate them accurately, completely and without omission. If they are able to do so, the readers will get the original meaning. Normally, the translators think that the best translations are produced by persons who are translating from their second language into their native language, because it is unusual for someone who has learned a second language to have total fluency in that language.

However, the prose-translators should not worry much about the 'loss of meaning', which may occur if the text describes a situation, which has elements that are unusual to the natural environment, institutions and culture of its language area, since the transference to the translator's language can only be estimated. As Derrida (2004) opines, "...perhaps a translation is devoted to ruin, to that form of memory or commemoration that is called ruin; ruin is perhaps its vocation and destiny that it accepts from the very outset" (p. 429). Even the most sacred and timeless original of them all "can undergo a maturing process" (Benjamin, 2004: 256) in translation, may unravel, open up and change, and it is precisely due to this change in the 'original', that "the translation will truly 
be a moment in the growth of the original, which will complete itself in enlarging itself" (Derrida, 1985: 188). Nevertheless, we must value the translator's work particularly because the 'go-between' (translator) perpetually works as a 'get-between'. However, it is generally thought that we constantly lose something in translation; conversely, we can also gain something from it. As Susan Bassnett (1980) mentions:

It is again an indication of the low status of translation that so much time should have been spent on discussing what is lost in the transfer of a text from S.L to T.L whilst ignoring what can also be gained, for the translator can at times enrich or clarify the S.L text as a direct result of the translation process. Moreover, what is often seen as 'lost' from the S.L context may be replaced in the T.L context. (p. 30)

\section{Conclusion}

In the end, since translation is simultaneously a theory and a practice, the translators, beside dealing with the difficulties inherent to the translation of prose, must think about the artistic features of the text, its exquisiteness and approach, as well as its marks (lexical, grammatical, or phonological). They should not forget that the stylistic marks of one language can be immensely different from another. "As far as the whole text is concerned, it is simply impossible to transfer all the message of the original text into the target text" (Yinhua, 2011: 169). However, the translators can try to find equivalence in translation and show the cautious nature of their assertions accordingly and request the readers to join and select which translation renders the thoughts, notions and words of the original text correctly.

The imperative suggestion is that the meaning of the translation is supposed to be the same in both the languages and the safety of the worthiness of the contents ought to be assured collectively. "Even when translation is indeed an 'absolute copy', it already 'summons the word by its name, wrenches it destructively from its context, but precisely thereby calls it back to its origin"” (Benjamin, 1978 [1931]: 269). Nonetheless, despite the fact that translation brings cultures nearer, in each translation, there will be a definite deformation between cultures. As Spivak (1993) comments, "The translator is not only part of her community of readers: she also comes into contact with another community, negotiating with it, taking part in it... One of the ways to get around the confines of one's 'identity' as one produces expository prose is to work at someone else's title, as one works with a language that belongs to many others" (p. 179). Yet, the translators should take the help from Silviano Santiago's (1978) term, 'double plagiarism' and take "properties from both the original literature and the receiving literature" and the translated text will be a "locus of encounter of two traditions, authorships and authorities" (Cited in Daly and Vieira, 1999: 7). Consequently, the prose-translators must not be anxious because it is feasible now to keep the S.L components in the target texts. According to Lahiri (2000), "Almost all of my characters are translators, insofar as they must make sense of the foreign to survive" (p. 120). However, the translators will have to defend the choices they make. Fortunately, there is an alternative now for including more 'foreign' words in certain prose. As Derrida (1985) appropriately utters:

To redeem in his own tongue that pure language exiled in the foreign tongue, to liberate by transposing this pure language captive in the work, such is the task of the translator. (p. 188)

\section{References}

Achebe, C. (1958). Things Fall Apart. London: Heinemann.

Adams, H., \& Searle, L. (Eds.). (1986). Critical Theory since 1965. Tallahassee: UP of Florida.

Adams, R. M. (1973). Proteus, His Lies, His Truth. New York: W.W. Norton.

Baker, M. (1992). In other words: A Coursebook on Translation. New York: Routledge.

Bassnett, S. (1980). Translation Studies. London: Methuen \& Co. Ltd.

Bassnett, S., \& Lefevere, A. (1998). Constructing Cultures: Essays on Literary Translation. Clevedon: Multilingual Matters.

Belloc, H. (1931). On Translation. Oxford: The Clarendon Press.

Benjamin, W. (1968). Illuminations (H. Zohn, Trans). New York: Shocken Books.

Benjamin, W. (1978). Karl Kraus. In Reflections (E. Jephcott, Trans.). New York: Harcourt Brace [1931].

Benjamin, W. (2004). Selected Writings: Vol. 1. The Task of the Translator (H. Zohn, Trans.). Cambridge, MA: Harvard University press [1923].

Benveniste, E. (1971). Problems in General Linguistics (M. E. Meek, Trans.). University of Miami Press, Coral Gables, Florida. 
Berman, A. (1995). Pour une critique des traductions: John Donne. Paris: Gallimard.

Bhabha, H. K. (1994). The Location of Culture. London: Routledge.

Bhatia, N. (Ed.). (1992). The Oxford Companion to the English Language. Oxford: Oxford University Press.

Blackburn, S. (1996). “implicature,” The Oxford Dictionary of Philosophy. Oxford: Oxford University Press.

Catford, J. C. (1965). A Linguistic Theory of Translation. London: Oxford University Press.

Cohen, J. M. (1986). Translation. Encyclopedia Americana, 27.

Crystal, Scott (2004). Back Translation: Same questions - different continent. In Communicate. London: Association of Translation Companies.

Daly, M., \& Vieira, E. R. P. (Eds.). (1999). 'The White Wall': Pre-facing Silviano Santiago. In Silviano Santiago in Conversation. Zoilus Press: London.

De Kock, L. (1992). Interview with Gayatri Chakravorty Spivak: New Nation Writers Conference in South Africa. ARIEL: A Review of International English Literature, 23(3). Retrieved from http://ariel.synergiesprairies.ca/ariel/index.php/ariel/article/viewFile/2505/2458

Derrida, J. (1985). Des Tours de Babel. In J. F. Graham (Ed.), Difference in Translation. Ithaca: Cornell University Press.

Derrida, J. (2004). What is a 'Relevant'Translatio. In L. Venuti (Ed.), The Translation Studies Reader (L. Venuti, Trans.). New York: Routledge.

Dimitriu, R. (2002). Theories and Practice of Translation. Iaşi: Institutul European.

Eagleton, T. (1977). Translation and Transformation. Stand, 19(3).

Gasche, R. (1988). The Saturnine Vision and the Question of Difference. Reflections on Walter Benjamin's Theory of Language. In R. Nagele (Ed.), Benjamin's Ground: New Readings of Walter Benjamin. Detroit: Wayne State U.P.

Gentzler, M. E. (1993). Contemporary Translation Theories. New York: Routledge.

Halverson, S. (1997). The Concept of Equivalence in Translation Studies. Target1-2(1997).

Harris, B., \& Sherwood, B. (1978). Translating as an Innate Skill. In D. Gerver \& H. Sinaiko (Eds.), Language, Interpretation and Communication. New York. Plenum Press.

Iser, W. (1974). The Implied Reader. Baltimore and London: The Johns Hopkins Press.

Jakobson, R. (1959). On Linguistic Aspects of Translation. In R. A. Brower (Ed.), On Translation. Cambridge, MA: Harvard University Press.

Kasparek, C. (1983). The Translator's Endless Toil. The Polish Review, 28(2).

Kenny, D. (1998). Equivalence. In M. Baker (Ed.), Routledge Encyclopaedia of Translation Studies. London and New York: Routledge.

Kollontai, A. (1977). Love of Worker Bees (C. Porter, Trans.). London: Virago.

Lahiri, J. (2000). My Intimate Alien. Outlook (New Delhi), special annual issue on "Stree" [Woman].

Liu, Z. (1991). Ten Lectures on Literary Translation. Beijing: China Translation and Publishing Corporation.

Lloyd, D. (1987). Nationalism and Minor Literature. Berkeley and London: University of California Press.

Macintrye, A. (1988). Whose Justice? Which Rationality?. London: Duckworth.

Man, P. de (1986). The Resistance to Theory. Minneapolis: Minnesota University Press.

Mann, T. (1984). The Magic Mountain (H.T. Lowe-Porter, Trans.). New York: Vintage Books.

Mann, T. (2011). Der Zauberberg. Location: Bange C. Gmbh.

Moliere. (2008). The Middle Class Gentleman [Le Bourgeois Gentilhomme] (P. D. Jones, Trans.). Retrieved January 31, 2010, from http://www.gutenberg.org/files/2992/2992-h/2992-h.htm

Newmark, P. (1988). A Textbook of Translation. New York \& London: Prentice Hall.

Nida, E. A. (1964). Towards a Science of Translating. With Special Reference to Principles and Procedures Involved in Bible Translating. Leiden: E. J. Brill.

Nida, E. A., \& Taber, C. R. (1982). The Theory and Practice of Translation. Leiden: E.J. Brill. 
Paz, O. (1971). Traduccion: Literatura y literalidad. Barcelona: Tusquets Editor.

Petrarch, F. (1985). Letters on Familiar Matters (Fam. XXIII, 19) vol. 3, books XVII-XXIV (A. S. Bernardo, Trans.). New York: State University of New York Press.

Pym, A. (1992). Natural and Directional Equivalence in Theories of Translation.

Rendall, S. (1997). Translation, Quotation, Iterability. TTR: Traduction, terminologie, redaction, 10(2).

Santiago, S. (1978). Uma literatura en os tropicos. Ensaios sobre dependencia cultural. Sao Paolo: Editora Perspectiva.

Sapir, E. (1956). Culture, Language and Personality. Berkeley, Los Angeles: University of California Press.

Sharp, J. (2008). Can the Subaltern Speak?. In Geographies of Postcolonialism. Thousand Oaks, CA: SAGE Publications.

Snell-Hornby, M. (1988). Translation Studies: An Integrated Approach. Amsterdam: John Benjamin.

Spivak, G. C. (1974). Translator's preface. In J. Derrida, Of Grammatology (G. C. Spivak, Trans.). Baltimore: Johns Hopkins University Press.

Spivak, G. C. (1990). The Post-Colonial Critic - Interviews, Strategies, Dialogues. New York: Routledge.

Spivak, G. C. (1993). The Politics of Translation. In Outside in the Teaching Machine. New York and London: Routledge.

Thierry, C. (1978). True Bilingualism and Second Language Learning. In D. Gerver \& H. Sinaiko (Eds.), Language, Interpretation and Communication. New York: Plenum Press.

Uspensky, B. A. (1973). A Poetics of Composition: The Structure of the Artistic Text and Typology of a Compositional Form (V. Zavarin \& S. Wittig, Trans.). Berkeley: University of California Press.

Venuti, L. (1995). The Translator's Invisibility. A History of Translation. London and New York: Routledge.

Vieira, E. R. P. (1999). Liberating Calibans: Readings of Anthropofagia and Haroldo de Campos' Poetics of Transcreation. In S. Bassnett \& H. Trivedi (Eds.), Post-colonial Translation. London/New York: Routledge.

Vinay, J. P., \& Darbelnet, J. (1995). Comparative Stylistics of French and English: A Methodology for Translation (J. C. Sager \& M. J. Hamel, Trans.). Amsterdam/Philadelphia: John Benjamins.

Webster, N. (1913). “Webster's Unabridged Dictionary”. University of Chicago reconstruction. Retrieved 2010-01-31.

Weedon, C. (1987). Feminist practice and poststructuralist theory. Cambridge, MA: Basil Blackwell.

Wiersema, N. (2004). Globalisation and Translation. Translation Journal, 8(1). Retrieved from http://translationjournal.net/journal//27liter.htm

Yinhua, X. (2011). Equivalence in Translation: Features and Necessity. International Journal of Humanities and Social Science, 1(10). 